\title{
Surface Structure of the Anodic Oxide Film of Aluminum and the Recovery Effect
}

\author{
Michiko Shimura \\ Fuculty of Engineering, Tokyo Metropolitan University
}

\begin{abstract}
The pore structure of anodic oxide film of aluminum has been studied by electron microscope when it was subjected to sudden decrease of the anodizing voltage (recovery effect). Either the direct observation on the peeled anodic oxide film or the indirect one with the two-step replica method was carried out for the samples anodized at the voltage decrease $14 \rightarrow 8 \mathrm{~V}$. To clarify the change of the structure due to the dissolution of the film, the barrier-type film was prepared and was subjected to the recovery effect in changes of electrolytes.

The obtained results are: (1) The pore structure at the early stage of the anodization in $\mathrm{H}_{2} \mathrm{SO}_{4}$ consists of primary pores which are called as cells, and the secondary ones, both forming colonies together. The two-step replica method doesn't reveal the fine pore structures because of the low dissolution and its usage is limited only to colony structure. (2) The change of pore structures, i. e., the enlargement of primary pore and the clarification of secondary pore were observed by the recovery effect when the voltage was decreased. The recovery of the flowing current is considered due to the recovery of the electric field across the barrier layer. (3) When the oxide film of barrier-type was transfered to sulfuric acid, the recovery of the current due to the change of the electrolyte was observed. In this case, the change of the structure was very clear and thred light on ambiguous point in result 2. The pores appeared at the current increasing point and became larger with the increase of the current, thus resulting in the establishment of cell structure. (4) The fact that the pore initiation by the recovery effect shown in result 3 became faster with the applied voltage can be attributed to the temperature rise with Joule's heat.
\end{abstract}

2-1-1 Fukazawa, Setagaya-ku, Tokyo 


\title{
アルミニウムのアノード酸化皮膜の構造と \\ 電 流の回 復効 果
}

志 村 美 知 子*

\begin{abstract}
要旨
アルミニウムのアノード酸化に执いて電圧の切り換えを行ならと電流に回復効果 (recovery effect) という過渡変化が生ずるが, それに伴うアノード皮膜の構造変化を電子顕微 鏡観察によって明らかにした。

実験は，先ず，硫酸中で，電圧を $14 \mathrm{~V} \rightarrow 8 \mathrm{~V}$ に切り換えたときの回復効果について，ハク 離皮膜法招よび二段レプリカ法で調べたが，明確な皮膜構造変化を得るために，次に，バ リヤー型皮膜について硫酸液中に括ける回復効果の際の皮膜構造変化を調べた。その結果,

1. 硫酸中で生成するアノード皮膜の初期の構造は, 発達孔 (primary pore) と未発達 孔 (secondary pore) によって構成され，さらに群によってまとめられている。二段レプ リカ法は解像力が劣るために, 硫酸化成皮膜のような微細構造のものには商していない。 これによると, 初期皮膜では群構造が顕著で, 他はあまり鮮明ではない。

2. 電圧変化による回復効果では, 発達孔の拡大と未発達孔の明確化が生じて, 多孔質 構造の変化が観察される。したがって電流の回復はバリヤ一層の溶解による電場の回復が 原因であると考兄られる。

3. バリヤー型皮膜を硫酸中に移したときには，電解液変化による電流の回復が観察さ れるが，その場合の皮膜の構造変化はきわめて鮮明であり，2.の不鮮明な個所を補足しう るものである。それによると, 電流がゼロの領域では外観上の変化がなく, 上昇し始める 点で孔の発生があり, 上昇中に孔の拡大とセル構造の確立が行なわれる。しかし, 七ル構 造の完成は電流が定常状態に回復した以後に行なわれる。
\end{abstract}

4. 3. 飞和いて印加電圧の影響が現われたが，それはジュール熱の液温の上昇効果によ るものと思われる。

\section{1. 緒言}

アルミニウムのアノード酸化に沏いて化成中に印加電 圧 $E_{1}$ を $E_{2}$ に切り換える操作（ただし $E_{1}>E_{2}$ ) を行な いその間の電流变化を観察すると, 電流は定常状態から 一たんゼロに降下ししばらくの後再び発生して新しい定 常電流値 $\left(E_{1}\right.$ の場合よりも低い定常電流値）飞到達す る。この電流の過渡現象を回復効果と呼んでいる。これ はMurphy1)によって提唱されたものであるが，この現 象はバリヤー層の表面電荷によって引き起こされると考 兄られた。この考えを要約すると, 問題の「バリヤー層

昭和 46.7 .26 受理

* 東京都立大学工学部工業化学科 世田谷区深沢 $2-1-1$
の表面電荷」とはアノード酸化反応の生成物であるプ ロトンによって作られるるのを指している（式(1))。 プロトンは生成と同時に皮膜外飞放出されるが一部がン゙ リヤー層中に閉じ込められて币の空間電荷を形成する。 そのため電流が皮膜中を流れるには（この場合の電流の 内容は $\mathrm{Al}^{3+}$ の泳動である）数々の障壁を乗り越光たの ちにさらにプロトン空間電荷によって作られた障壁を乗 り越光ねばならず，それだけ余計に駆動力が要求され る。印加電圧を瞬間的に下げたときには駆動力が不足す ることになるため電流が流れなくなる。ところが時間と ともにプロトン空間電荷が放電されるとこれによって作 られていた障壁が緩和されるので電流が再生するように なる。つまり電流の回復はプロトン空間電荷の放電によ って起こると解釈された。 


$$
\left.\begin{array}{l}
2 \mathrm{Al}^{3+}+3 \mathrm{OH}^{-} \longrightarrow \mathrm{Al}_{2} \mathrm{O}_{3}+3 \mathrm{H}^{+} \\
2 \mathrm{Al}^{3+}+3 \mathrm{H}_{2} \mathrm{O} \longrightarrow \mathrm{Al}_{2} \mathrm{O}_{3}+6 \mathrm{H}^{+}
\end{array}\right\}
$$

ところが回復効果には強い温度依存性 ${ }^{2)}$ があり，この 間の溶出 $\mathrm{Al}^{3+}$ 量を測定した結果からはバリヤー層の溶 解によるとみられる $\mathrm{A} 1^{3+}$ の増加があるなど ${ }^{3)}, \quad$ プロト ン空間電荷の放電とする解釈には疑問な点が多い。

本報は回復効果に伴う皮膜構造変化を電子顕微鏡を用 いて調ベ，バリヤー層の溶解を確認した結果と多孔質構 造についての 2,3 の知見について述べる。

\section{2. 実験}

\section{1 試料および前処理}

試料は純度 $99.99 \%$ の $\mathrm{Al}$ ハクで， $1 \times 2.5 \mathrm{~cm}$ 犒よび $2 \times 3.5 \mathrm{~cm}$ の短冊型のもので, アセトンで脱脂したのち リン酸ークロム酸-硫酸系の電解研摩液中で電解研摩し, アノード酸化に用いる直前に電解研摩皮膜をリン酸ーク ロム酸混液中で溶解する処理を行なった。

\section{2 アノード酸化}

電流の回復効果は次のような 2 種のアノード酸化に括 いて生起させた。

2.2.1 印加電圧を変化させたときの電流の回復効果

これは Murphy のいら回復効果を生起させる方法で ある。二台の定電圧装置を用意し，一方を $E_{1}$ の電源他 方を $E_{2}$ の電源として使用する。この場合 $E_{1}$ は $14 \mathrm{~V}$, $E_{2}$ は $8 \mathrm{~V}$ と設定した。電源, 電解槽, 電流記録装置の 関係を図-1 に示す。電流の記録に当たっては三栄测器 K. K. 製の電磁オッシログラフを用いた。

電解液は $\mathrm{pH} 0.6$ の硫酸（ 0.13 重量モル濃度）で，液 温は $10,25,40^{\circ} \mathrm{C}$ とした。

カソードは $4 \times 12 \mathrm{~cm}$ の $\mathrm{Al}$ ハクで作った円筒形のも ので,この中央に試料のアノードを吊した。

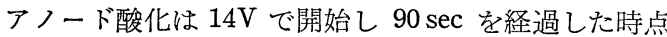
で電源を $8 \mathrm{~V}$ に切り換え電流が完全に回復するまでアノ ード酸化を続けた。

2.2 .2 電解液を変化させたときの電流の回復効果

これは、本来の定義を拡張したもので, 電解液を変化さ

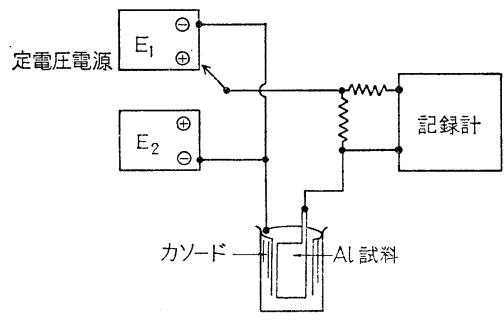

図-1アノノード酸化回路
せることによって得られる回復効果である。印加電圧を 変化させないので電源は一台となるが，電解液を交換す るに際して中間に水洗過程が加わるところからこの間に 時間の経過が起こる。この点が先さとはなはだ異なる点 である。

電解液は $\mathrm{pH} 6.8$ 酒石酸アンモン（0.15 重量モル濃 度, 酒石酸添加) と $\mathrm{pH} 0.6$ 硫酸（0.13 重量モル濃度） とし, 液温は $25^{\circ} \mathrm{C}$ に定めた。

印加電圧は $25,15,5 \mathrm{~V}$ の 3 種類をとった。カソード や電流記録装置などについては先きと同じである。

アノード酸化は先ず酒石酸アンモン液中で行ない3 min を経過したところで電源を切り, 試料の水洗を行 なった。水洗は水道水, 蒸留水の順で行ない, 約 $10 \mathrm{~min}$ を要した。次に硫酸中でアノード酸化を行ない, 電流が 完全に回復した時点で電解を終了した。な牧電解液交換 に際して試料は常にぬれたままの状態においた。

\section{3 電子顕微鏡観察}

アノード酸化皮膜を直接観察する場合には皮膜をヨー ド・メタノール法でハク離し，直接倍率 30,000 で観察 した。

一方レプリカ法で観察する場合にはアセチルセルロー ス（一段目レプリカ）之, pt-pd, c 蒸着（二段目レプ リカ）とによる二段レプリカ法を用い，直接倍率 30,000 で観察した。

\section{3. 結果および考察}

\section{1 印加電圧を変化させたときの回復効果}

図-2 は硫酸 $25^{\circ} \mathrm{C}$ に执いて $14 \mathrm{~V}$ でアノード酸化を開 始し $90 \mathrm{sec}$ 経たところで $8 \mathrm{~V}$ に印加電圧を切り換えた ときの電流の回復効果を示している。電流が再び定常状 態に戻るのに $36 \mathrm{~min}$ かかった。

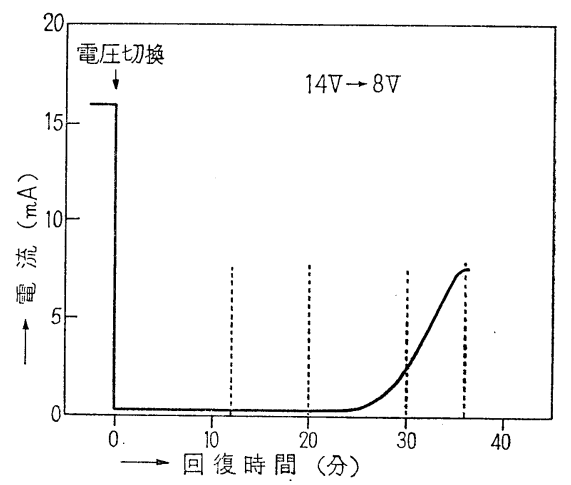

図-2 電圧变化による電流の回復効果 $\mathrm{E}_{1}=14 \mathrm{~V}$ $E_{2}=8 \mathrm{~V} \quad \mathrm{pH} 0.6 \mathrm{H}_{2} \mathrm{SO}_{4}, 25^{\circ} \mathrm{C}$, 点線は電子 顕微鏡観察を行なった段階を示している 
写真-1 は $36 \mathrm{~min}$ の回復期間中の種々の時点における 皮膜構造をハク離皮膜法で観察したものである。

ここで先ず硫酸化成皮膜の多孔質構造を明らかにして 和くと, 電子線が最もよく透過した（写真で白色の）部 分之透過の悪い（黒色の）部分と両者の中間の部分（死 色）とから成り立っている。前者の二つはそれぞれ孔と その壁であることが一見して分るが，後者は倍率を高度 飞上げたときにようやく微細な孔の密集部分であること が判明する。前者を発達孔（primary pore），後者を未 発達孔 (secondary pore) と呼ぶことにしよう。発達孔 は，その底にある酸化物層（バリヤー層）がうすい（し たがって電場が高い）ために化成中にイオン電流の通過 を許し，酸化物の生成と溶解とを起こすが，未発達孔は その底のバリヤー層がすでに厚くなっているために発達 孔と同様の機能を果たさなくなっていると考えられる。 両者により硫酸化成皮膜の初期の構造を考えると図-3 のようになるであろら (後述)。

次に, 回復効果の際の多孔質構造の変化をみていく と，電流がゼロに停滞するところでは変化がないが急上 昇後に初めて発達孔の面積の拡大（ただし個数は変化し ない。図-4 参照) と未発達孔の明確化という変化が検 出される。これらは溶解によって生じた変化であること は明らかである。たとえば未発達孔の明確化はその底に あるバリヤー層が溶解によってらすくなった結果電子線 を透過しやすくなったものと解釈される。したがって電 流の回復はバリヤー層の溶解により電場が増大したこと によると考えられる(後述)。

\section{2 八ク離皮膜法とレプリカ法との対応について}

写真-2 は写真-1 の試料の外表面のみを二段レプリカ 法で観察しな和したものである。得られた像の大きさは 先さと明らかに違っている。そこで二段レプリカ像の信 ぴよう性を検討する必要がある。ハク離皮膜法では約

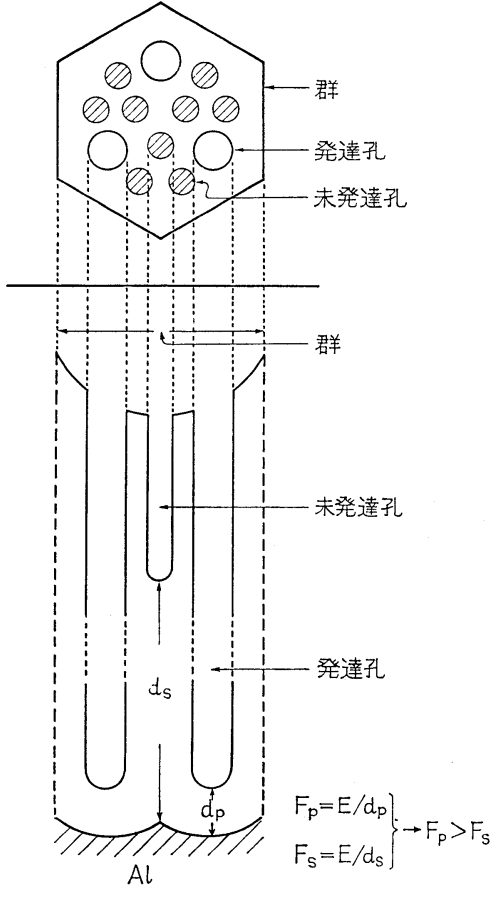

図-3 アルミニウムのアノード酸化皮膜の初期構造

50Åの未発達孔までが検出されるほど解像力がすぐれて いたので，それによる多孔質構造を基準にとると，次の ようなものであった。すなわち多孔質構造は発達孔の密 度によって特徴つけられるものである。発達孔は内径, $r$ と壁の厚さ， $d$ とがともに約 100〜200Å の大ささに ある。したがって $r+d=400 \AA ̊$ が多孔質構造を構成する 単位（セル）の大きさということになる。セルは数個ず つでまとまりをもっている。これは群（colony）と呼ば れるべき単位のもので, アノード酸化の極く初期に多孔 質構造がまだ未確立のときにしばしば観察されるもので
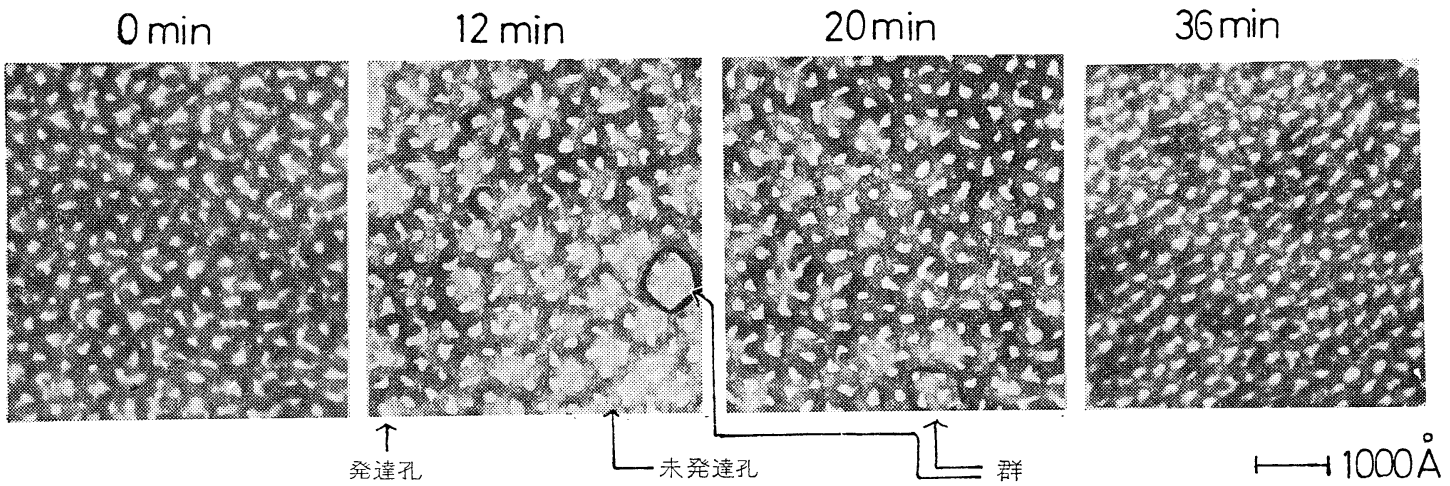

写真-1 回復効果に伴万多孔質構造の变化（ハク離皮膜法による，倍率 90,000） $E_{1}=14 \mathrm{~V}, E_{2}=8 \mathrm{~V}, \mathrm{pH} 0.6 \mathrm{H}_{2} \mathrm{SO}_{4}, 25^{\circ} \mathrm{C}$ 


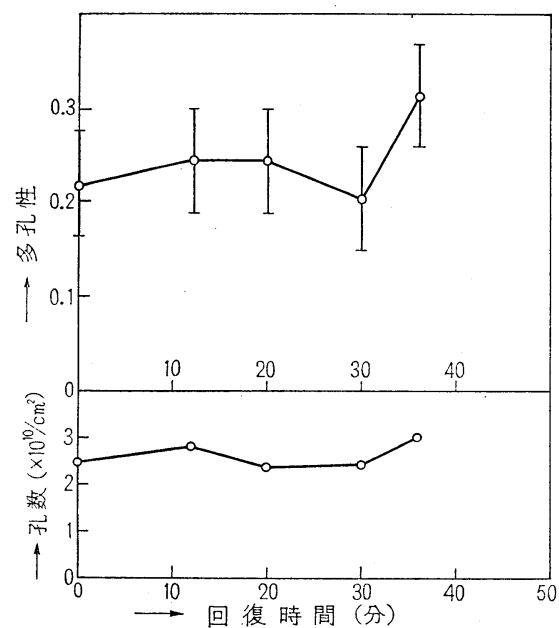

図-4 回復効果の際の多孔質構造の変化（ハク離皮 膜法 倍率 18 万の写真 $3 \times 3 \mathrm{~cm}$ での視野 3 個 所からの平均值から求めた）

ある4)。このほかすでに述べたように未発達孔がある。 以上のようにアノード皮膜の構成は複雑でしかも微細で ある。それに対して二段レプリカ法のもつ解像力は約 $150 \AA$ が限界であるから未発達孔はもちろんのこと, 問 題の発達孔の内径や壁の厚さの判別もむずかしいことが 予想される。事実, 写真-2 に得られた像は（写真-1 に 対比させると), $12 \mathrm{~min}$ がセルの大きさ, $20 \mathrm{~min}$ は群, そして $36 \mathrm{~min}$ が発達孔の内径となって扣り, 発達孔の 内径はなかなか得られない。 $36 \mathrm{~min}$ に和いて得ること がでさたのは，とりもな拈さず，孔が溶解によって解像 力の限界内に入る大きさに拡大したためである。群など による混同や像の判別のむずかしさを考えると，二段レ プリカ法によって回復効果に和ける皮膜構造变化を求め ることはかなり問題があるといわねばならない。
それでは二段レプリカ法は硫酸化成皮膜の構造変化に 対して全く無効なのであろうか。写真-3 はアノード皮 膜をリン酸ークロム酸混合液中で溶し去り露呈した金属 面を二段レプリカ法で観察したものである。得られた像 を写真-1 と対比させると，これらは相当する皮膜のセ ルの大きさにのみ一致している。そのため先きのような 群などの混同が完全に解消される。そこで, 金属面上の 凹凸から皮膜の構造変化を調べていくことにしよう。先 ず，電流がゼロの領域に特いてはセル構造には時間的変 化がみられない。ところが急上昇後に急激な細分化がみ られる。これは電流が上昇する際にセル構造が作りか光 られて行くことを示すものであって，流れた電流は金属 $\mathrm{A} 1$ の解離 $\left([\mathrm{Al}]_{n} \rightarrow \mathrm{Al}^{3+}+3 e\right)$ を伴う $\mathrm{Al}^{3+}$ の泳動電流 であることを示している。そのため，Murphy が考えた ような, Al の解離と無関係な, バリヤ一層表面に蓄積 された空間電荷の放電による電流ではない。電流がゼロ の領域でセル構造に変化がないのは $\mathrm{Al}^{3+}$ の泳動が抑兄 られているからである。 $\mathrm{Al}^{3+}$ の泳動は, 金属 $\mathrm{Al}$ からの 解離過程 $\left(\mathrm{Al} \rightarrow \mathrm{Al}^{3+}+3 e\right)$ とバリヤー層内の泳動過程を 経過することによって起こるがそのらちで律速段階はバ リヤー層内の泳動にあると考えられる。そのためイオン 電流を通過させるには，バリヤ一層内の高い活性化障壁 を外部から高電場をかけて障壁のレベルを傾け，相対的 に活性化障壁を軽減してやらなければならない。印加電 圧を切り換えると $(8 \mathrm{~V} に)$ ，イオン電流が消滅するのは 電場 $F(F=E / d$, ただし $d$ は barrier 層の厚さ) が減少 して活性化障壁を軽減させる効果が少くなったことによ るのである。いま，印加電圧は $8 \mathrm{~V}$ 亿和さえられている から，このような状態で電場がもとの值に回復するには バリヤー層の厚さが減少するのを待つ以外ない。そこで 電流が再生するまでの誘導期間（これまでみてきた電流

\section{$12 \mathrm{~min}$}

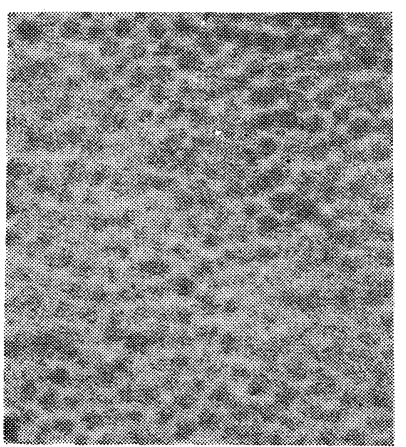

20 min

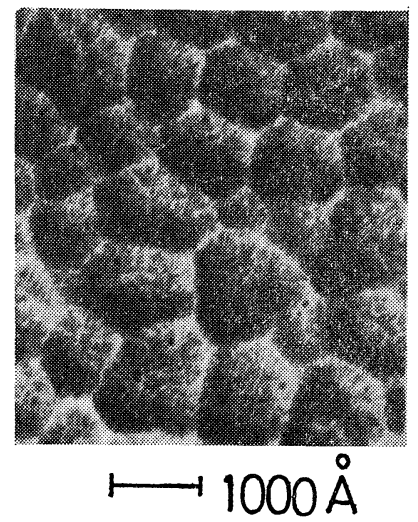

36 min

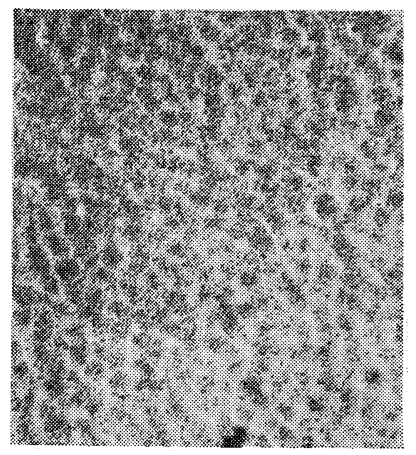

写真-2 写真-1 の試料の皮膜の外表面状態（二段レプリカ法 倍率 90,000） 

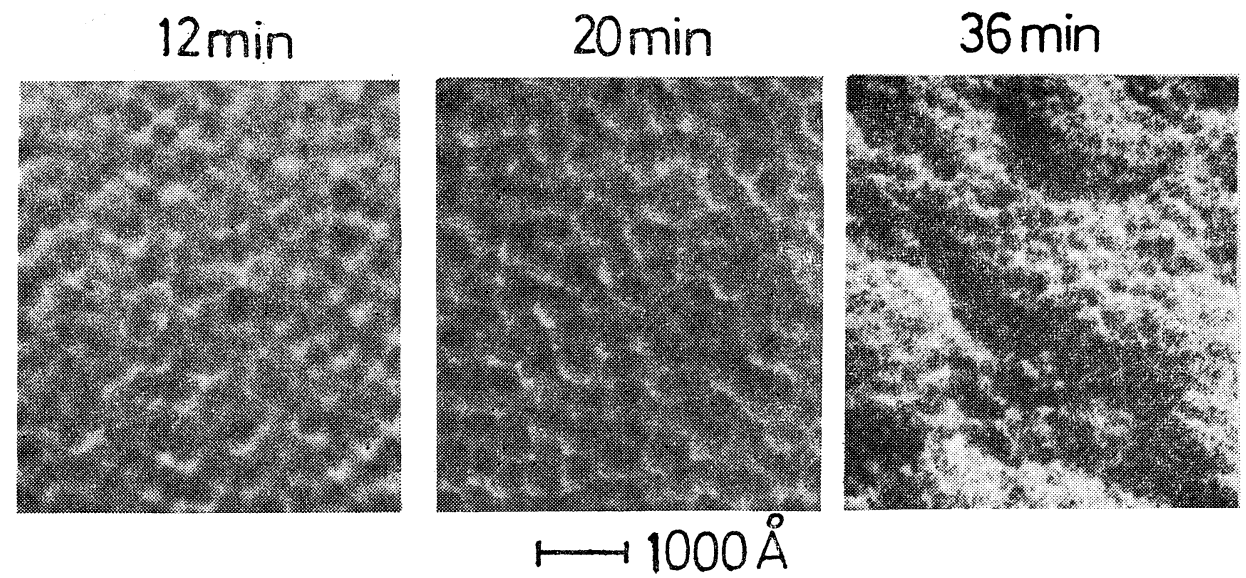

写真-3 写真-1 の試料の金属表面状態（二段レプリカ法 倍率 90,000）

ゼロの領域）はバリヤー層が溶解して電場が回復するま での時間ということになる。これは電解液の温度に強く 依存し， pH にも依存することが知られて物り，化学的 現象であることが裏付けられている。

以上のように，金属表面上には $\mathrm{Al}$ の解離跡が残る (これはセル構造に一致する) ことから, 回復効果にお ける皮膜の構造変化を求めることができる。

しかし，もともと多孔質構造であるところに回復効果 による変化を求めるのであるから明確な形で求めにくい のは当然である。そこで次節のような実験を試みた。

\section{3 電解液を変化させたときの回復効果}

回復効果に拉㺭る皮膜の構造变化を明確な形で求める ために, バリヤー層上に回復効果を試みた。実験は次の通 りである。バリヤー型皮膜の形成には酒石酸アンモン 液中でのアノード酸化を行ない，これを硫酸液中に移し て前節と同様の電圧の切り換えを行なった。ところが電 流の回復がなかなか起こらなかったので, 降下させるべ き電圧 $\Delta E\left(\Delta E=E_{1}-E_{2}\right)$ を徐々に減らした。その結果 $\Delta E=0$ すなわち印加電圧を全く変えないときでも, 電解 液の交換といら変化だけで, 電流の回復が起こり, その 回復時間は測定に都合のよい長さであることが見いださ れた。そして曲線の形は 3.1 にみてきた回復効果の曲線 と全く同じタイプであることが見いだされた。そこで電 解液交換による電流の回復現象について, 皮膜の構造変 化を追跡した。その結果を図-5，6，7 に示すが，印加 電圧が高い場合には電流の回復がきわめて速く, 回復後 の定常電流值が高いといら現象が見いだされた。すなわ ち20V では $3 \mathrm{~min} 30 \mathrm{sec}$ で電流が完全に回復した（15 $\mathrm{V}$ も注ぼ同じ）のに対し $5 \mathrm{~V}$ では $7 \mathrm{~min}$ を要した。こ らした現象が現われる理由についてはのらに考えるつも りである。いまは電流回復過程に拉ける皮膜の構造変化
を明らかにして抗こら。写真はハク離皮膜法によるもの である。先ず, 酒石酸アンモン液中で生成した段階の皮

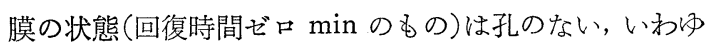
るバリヤー型であり，印加電圧を $20 ， 15 ， 5 \mathrm{~V}$ の 3 種と していたが，相互の相違は認められなかった。バリヤー 型皮膜の厚さは電流が十分に降下した状態では, 電圧と $14 \AA / \mathrm{V}$ の関係があるから，これらは $20 \mathrm{~V}$ では $280 \AA ̊$ $15 \mathrm{~V}$ では $210 \AA ， 5 \mathrm{~V}$ では $70 \AA$ の厚さに達していると推 定される。次に硫酸中での変化をみると, 電流がゼロに 停滞する領域 (20V に和ける $1 \mathrm{~min}, 5 \mathrm{~V}$ に和ける $2 \mathrm{~min}$ ) ではな特バリヤー型であり，何ら変化がみられない。と ころが電流が再生し始めた点 (15V に特ける $1 \mathrm{~min} 30$ sec) では，皮膜全面に小粒子が無数に発生するように なっている。そして電流急上昇域の中間段階 $(20 \mathrm{~V}$ に拉 ける $2 \mathrm{~min} 30 \mathrm{sec}, 15 \mathrm{~V}$ に和ける $2 \mathrm{~min} 15 \mathrm{sec}$ ) では粒子 の径の拡大が起きて孔へと生長している。しかしこのと き生長の起こるのは点在する一部の粒子であって, 他は ほとんど未発達のままにある。すなわちここに和いて発 達孔に至るものと未発達孔のままのものとの区別が生じ ている。次に電流が完全に回復した時点（15Vに扣ける $3 \mathrm{~min} 30 \mathrm{sec}, 5 \mathrm{~V}$ に和ける $7 \mathrm{~min}$ ) では, 発達孔の方は さらに拡大して, 隣接の孔と融合するなどにより, 円形 のものが長円形などに変形を起こしている。一方, 未発 達孔はそのままの大きさにある。そして電子線がかなり 不透過となってきている。これはのちに検出されなくな るものである。電流が完全に回復した時点では発達孔は 数個ずつまとまって群（colony）を形成しているが，こ れは多孔質層が構造上まだ未完成の段階にあることを示 している。

以上の結果から，バリヤー型皮膜を硫酸中に移して再 びアノード分極をするときの電流の回復は, バリャー層 


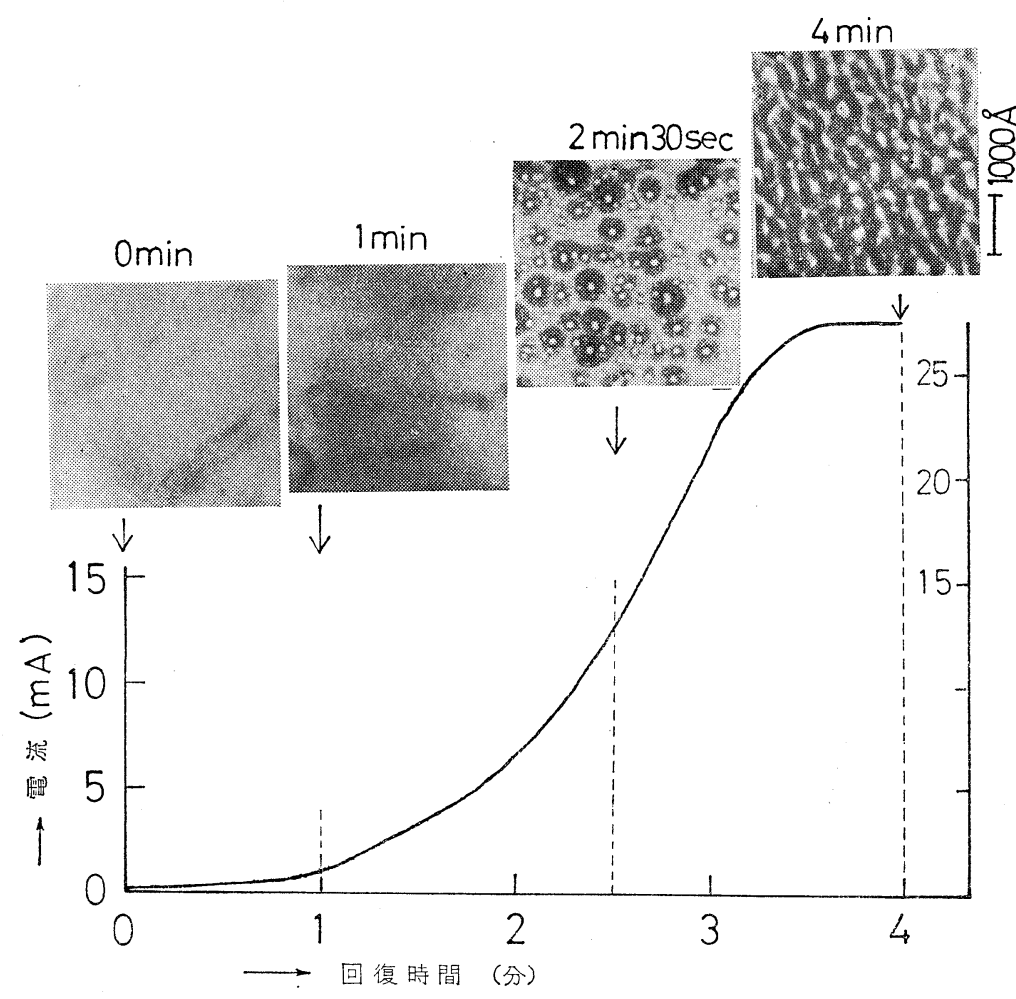

図-5 電解液交換による回復効果と皮膜構造の変化との関係。 印加電圧 $20 \mathrm{~V}, 25^{\circ} \mathrm{C}$ ( (ハク離皮膜法 倍率 90,000 )

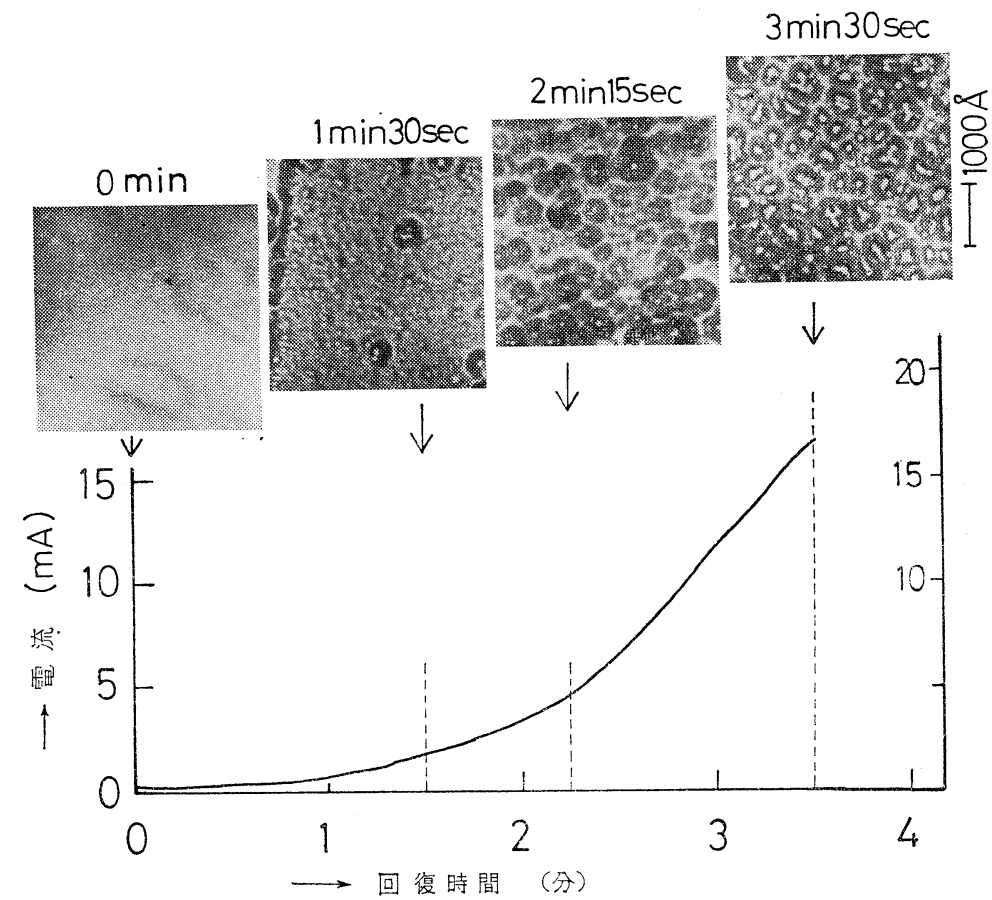

図-6 電解液交換による回復効果と皮膜構造の变化との関係 印加電圧 $15 \mathrm{~V}, 25^{\circ} \mathrm{C}$ (八ク離皮膜法 倍率 90,000)
の溶解に起因することが明らかと なった。この場合の多孔質化への 推移は鮮明で, 各段階の状態を明 確にとらえることができた。この 過程は, 3.1 に述べてきた回復効 果に和ける構造変化の不鮮明な個 所を明らかにしらるものと考光 る。そしてまた，アノード酸化の 極く初期に起こる多孔質化過程に 対してる適応しうると考える。

さて，先さに観察された「印加 電圧が高いと電流の回復が速く, 回復後の定常電流值が高い」現象 について考えてみよう。通常，イ オン電流については電場 $F$ と式 (2)の関係があるが, バリヤー層 の生長によって電場 $E / d$ が十分 に小さくなったときにはイオン電 流が消隇して漏れ電流のみが残る こととなる5（いままでイオン電 流のない領域を電流ゼロの領域と いってきたがそれは厳密には正し くない)。漏孔電流は電子電流で あってオーム則が成立つことは式 (3)から明らかである。

$$
i=A \exp B F=A \exp B \cdot E / d
$$

$i_{l}=\vec{i}-\overleftarrow{i}=A \exp B \cdot E / d-A \exp$

$$
(-B \cdot E / d)
$$$$
=A(B / d)\left\{\left(1+\frac{E}{1 !}+\frac{E^{2}}{2 !}+\cdots\right)\right.
$$$$
-\left(1-\frac{E}{1 !}+\frac{E^{2}}{2 !}-\cdots\right)
$$$$
\doteqdot A(B / d) \cdot 2 E=(1 / R) \cdot E
$$

したがって電子電流によるジュ一 ル熱の発生を考える必要がある。 ジュール熱は電場によって加速さ れた電子がその運動のエネルギー を酸化物の原子に与えるために， 原子の熱振動が強められることに よる熱であって, $W=E \cdot I=E^{2} / R$ （ただし $W$ はシュール熱， $R$ はバ リヤー層の抵抗で $\left.R=r_{0} \cdot l / S\right)$ で 表わされる。ここではバリヤー層 の厚さ $d$ は印加電圧 $E$ と $l=14 \times$ $10^{-8} \cdot E$ の関係にあるから, ジュ 


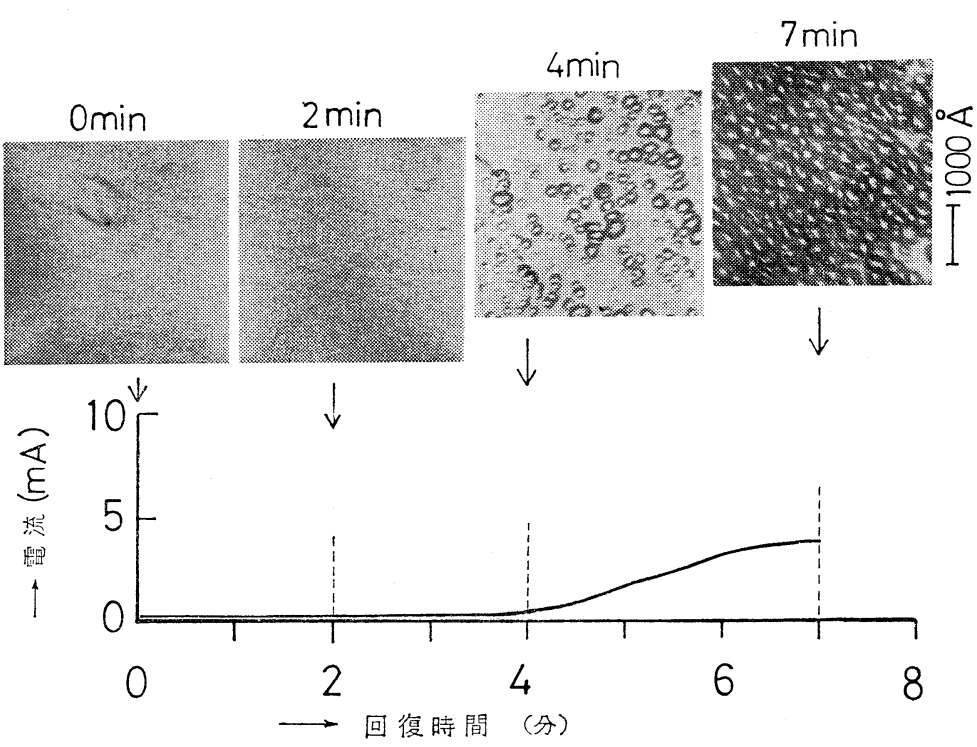

図-7 電解液交換による回復効果と皮膜構造の変化との関係。 印加電圧 $5 \mathrm{~V}, 25^{\circ} \mathrm{C}$ (ハク離皮膜法 倍率 90,000)
「印加電圧が高いと定常電流值が高 くなる」現象については次のように 考えられる。イオン電流の再生は, バリヤー層が溶解して電場が回復す ることによって起こるから，大きな ジュール熱(印加電圧の大きいとき) が発生して液温が上昇したときには 回復した電場の值が大きく，そのた め式 (2)で示されるイオン電流值が 大きくなるのである。イオン電流は 再生するとのちに定常状態に達する が，それはとの状態での溶解速度と 均り合らよらになるからである。つ まりイオン電流は新たにバリヤ一層 を供給するが，溶解の方は生じたバ リヤー層を除去するよらに作用す る。この両者が互に速度が等しいと きに，イオン電流は定常的に流れる のである。印加電圧が高いときにイ
一ル熱は印加電圧に比例するものとなる（式 (4))。

$$
\begin{aligned}
W & =E^{2} /\left(r_{0} \cdot 14 \times 10^{-8} E / S\right) \\
& =\left(S / 14 \times 10^{-8} r_{0}\right) \cdot E
\end{aligned}
$$

いまバリヤー層の液中に括ける比抵抗を $r_{0}=10^{8} \Omega \cdot \mathrm{cm}$ とすると（液中に捈けるインピーダンスの測定から求め $\left.た^{6)}\right)$, 試料の面積はこの場合 $S=14 \mathrm{~cm}^{2}$ であるから, $W=1 \cdot E$ joule $/ \mathrm{sec}$ となって, $E=20 \mathrm{~V}$ のとさには $W=20$ joule $/ \mathrm{sec}, E=5 \mathrm{~V}$ のときは $W=5$ joule $/ \mathrm{sec}$ となる。した がってかなりの発熱量である。一方熱の拡散は, アルミ ナの熱伝導度が $0.05 〜 0.015 \mathrm{cal} / \mathrm{cm} \cdot \mathrm{sec} \cdot \mathrm{deg}$ (ただし乾 燥した鋼玉の場合について。溶液中については不明）で あることから推定すると, バリヤー層内に蓄積される熱 は無視できると考えられる。すると先きの発熱エネルギ 一は直らに電解液を温めることとなるから, 本実験のよ らに液量が少なくしかも静止した状態では液温が上るこ とが考えられる。したがって液温の上昇がバリヤー層の 溶解速度を促進し, 電流の回復を速める原因となってい ると考えられる。以上の説明は「印加電圧が高いと電流 の回復が速くなる」現象についてであるが，もら一つの
オン電流值が大きいのは, 溶解速度が大きいことを示し ている。

以上述べてきたよらに回復効果に伴い皮膜に溶解が起 き, 構造変化が起こるが, 同時に皮膜は酸性点を有して 活性化されることを付記して和こう。

(一部日本化学会第 24 年会にて発表)

$$
\text { 文献 }
$$

1) J.F. Murphy: Proceedings of "Symposium on Anodizing Aluminium” Birmingham, April (1967)

2) 志村美知子, 電気化学, 39, 230 (1971) M. Shimura, : Jr.Electrochem. Soc., 118, 1094 (1971)

3）永山政一, 田村和利, 高橋英明, 第 15 回腐食防 食討論会要旨集 p. 131, 北九州 (1969)

4) 志村美知子, 電気化学, 39, 821, (1971)

5) L. Young: "Anodic Oxide Films", p. 12 Academic Press, London and New York (1961)

6）志村美知子, 電気化学, 40，1 月号（1972）

7）志村美知子, 未発表 